\title{
Regulating the Use of Commercial Drones: Quest for Finding A Space Within Airspace - An Asian Perspective
}

\author{
Prof. (Dr.) Raju K.D \\ B.Sc, LL.M (MGU), M.Phil, Ph.D. (JNU), Fulbright Fellow, Microsoft Outstanding Young Faculty Fellow, \\ presently he is Professor of Law at Rajiv Gandhi School of Intellectual Property Law, IIT Kharagpur \\ Vijay Kumar \\ Assistant Professor (Law) Reva University Bangalore, India. Research Scholar at Rajiv Gandhi School of \\ Intellectual Property Law, IIT Kharagpur
}

The paper is a modified version of work presented during the $7^{\text {th }}$ Biennial Conference organized by the Asian Society of International Law from $22^{\text {nd }}$ to August 232019 held in Manila, Philippines.

\section{Abstract}

The advent of Unmanned Aerial Vehicle (UAV) has significantly affected the navigational route of the existing aviation system. Though there are sufficiently developed air routes for national and international flights, the drones have become a threat or at least an encroachment upon those peaceable use of the air navigational routes. At several reported instances, close collisions of aircraft and drones got averted that would have otherwise caused severe disturbances to the paths of the aircraft. On the request of its Member-States, the International Civil Aviation Organisation (ICAO) has developed a model for drone regulations. However, such regulations need uniformity and consanguinity among national regulations that complement global initiatives. Thus, this paper seeks to analyze the prevalent Asian practices on drone regulations. Since the technology has got its imminence in Asian markets such as Hong Kong and Singapore with future scope for other Asian countries, the authors make a comparative analysis of "policies" of Asian countries, with the policies of the European Union and the United States. In conclusion, the paper prefers an argument for developing a dedicated Unmanned Aircraft Systems (UAS) for drones within the currently available flying zones so that any future misfortunes could be averted.

Keywords: Drones, Asia, International, Policy, Navigation, Regulation.

DOI: $10.7176 / \mathrm{JAAS} / 71-05$

Publication date: April $30^{\text {th }} 2021$

\section{Introduction}

The use of unmanned aerial vehicles (UAVs) or remotely piloted aviation systems (RPAS), popularly known as "drones" for military purposes, have been in place for quite a long period with the different technologies at different times. ${ }^{1}$ The modernized drone technology used for military purposes drawn global attention during American strikes in Iraq, Afghanistan, and the tribal areas of Pakistan. The military use of drones infused the discussion and constituted the basis for the commercial use of drones. ${ }^{2}$ The first form of developing drones was reported back in 1849 when the Australians attacked Venice with bomb-laden balloons. ${ }^{3}$ However, the first active use of "flying bombs" was done by the US in 1918. During the 1980s, Israel used flying drones for attacking its enemies and to the precision targets. As modern technology paved the way for small drones, making them available for purchase at low prices; hence the rise of drones in public space is pre-empted.

The forecast is that the use of commercial drones will become widespread in the next five to ten years, especially in the transportation of logistics of small, light items. ${ }^{4}$ The drones have developed in many formats for different purposes, with many identified applications and many more anticipated. ${ }^{5}$ Various companies involved in the delivery of goods sectors have already invested in developing such drone delivery systems. In 2013 Amazon announced that it would use drones for the delivery of goods. ${ }^{6}$ In the coming years, drones will inflate, or in some scenarios, may replace trucks or other roadways transport vehicles. advent and trends of shopping through online networks where almost eighty percent of the consumers' orders weigh five lbs or less - the use of drones in the delivery of such products will increase. ${ }^{7}$ This augmented role of drones in commercial use will have severe implications for many issues such as energy consumption, public safety, privacy, pollution, air traffic management, and many more. ${ }^{8}$ It is expected to supersede the commercial drone market by 2021 against the military use of drones to the extent of US $\$ 900$ million only in India, and the global market is going to be worth US\$ 21.47 billion. $^{9}$ India tops in importing drones in 2019 and will be one of the growing markets for commercial drones.

The drones can be used in various social activities such as use by State machinery to prevent crimes, during riots, disasters, surveillance, etc., and by private sectors for aerial photography, cinematography, and agriculture. ${ }^{10}$ However, the reckless operation without following the regulations may cause mayhem to various things. One of the more significant issues is that people fly drones near airports, which may cause hazards to the 
aircraft and aviation routes. ${ }^{11}$ Another emerging challenge is that the new technological advancement in drone technology has made it possible to fly at high altitudes and long-range coverage across another country - to regulate such activities requires initiatives from the international community. Thus, there is a need to develop a regulatory regime for national and international activities as well.

The twenty-first century has brought to the people a proliferated aerial vehicle that does fly without a pilot on board. ${ }^{12}$ Such drones are controlled by pilots nearby on the ground, in some cases remotely controlled from far away or perform automatically. However, such capabilities are not immune to risks. Drones also cause chilling effects on privacy and security concerns that need to be addressed domestically and internationally. ${ }^{13}$

The flying zone of drones substantially encroaches upon the air space, which traditionally been used by the aircraftthe aircraft. These encroachments have the potential to cause a severe threat of accidents. Such threats require urgent attention of the global community to develop an internationally acceptable regulatory mechanism for the smooth development of the technology.

Since the beginning of the civil aviation sector, the international community has promptly addressed the regulatory or legal challenges for maximum realization of the economic benefit of the sector. The primary international instrument governing the aviation sector is the Convention on International Civil Aviation, 1944, popularly known as the Chicago Convention. ${ }^{14}$ The Member States to the Convention "agreed on certain principles and arrangements so that international civil aviation may be developed in a safe and orderly manner and that international air transport services may be established based on equality of opportunity and operated soundly and economically." The United Nations, due to the economic relevance of the sector, took the lead in developing the global rule-based mechanism. Aviation is only a specific commercial sector that has got a specialized United Nations body.

The International Civil Aviation Organization (ICAO) was established in 1944 under the Chicago Convention "to manage the administration and governance of the" international civil aviation. ${ }^{15}$ The ICAO works with its member states and industry groups to develop consensus-based "Standards and Recommended Practices (SARPs) and policies in support of a safe, efficient, secure, economically sustainable, and environmentally responsible civil aviation sector. The ICAO Member States uses these SARPs and policies to ensure that their local civil aviation operations and regulations conform to global norms". ${ }^{16}$ Therefore, the ICAO manages the international civil aviation and domestic civil aviation indirectly through SARPs.

However, the advent of drones for civilian or commercial purposes has put the ICAO at the spot to develop an adequate regulatory framework for the international community. As it has been feared by Peter van Blyenburgh that:

"If a solution is not found, we will run the risk of seeing a multitude of inadequate national regulations being created in many countries where the societal benefits and/or the financial rewards of drone use could outweigh their safe use. In turn, this could result in decreasing aviation safety overall in the countries concerned." 17

The International Air Transport Association (IATA) also raises similar concerns that the exponential growth of commercial use of Remotely-piloted aircraft (RPAs)/drones is "operating dangerously close to manned aircraft and airports." ${ }^{18}$ It is visibly apparent that drone technology is growing up, and the manufactures and operators are striving for greater access to airspace, including the traditional airspace, which is being used by aircraft.

Due to the absence of any comprehensive international framework for drone regulation - different countries are struggling to adapt current laws to new technology, and it substantially varies from country to country. Since the flying zones of drones are mainly falling to the airspace, which has been used by the aircraft, the ICAO, as a regulatory body, has efficiently managed and developed the regulatory framework for aviation could lead to the same for the drones. ICAO has considered the operation of drones the first time in 2011, issued a circular titled Unmanned Aircraft Systems (UAS). ${ }^{19}$ Considering the prior experience of the ICAO in managing the airspace, as argued, the ICAO will be an appropriate organization to address the drone issues.

Hence, in this paper, the authors intend to analyze, in part one, the prevalent Asian practices on drone regulations. The authors explore the drone regulations of India, China, Hong Kong, Singapore, and Japan in detail. In part two, the paper comparatively examines the policies and regulatory mechanisms of the European Union (EU) and the United States (US). In the concluding part, the authors evaluate an argument for having a complete Unmanned Aircraft Systems (UAS) providing separate navigational paths and flying zones for drones within the currently available flying zones so that any future misfortunes could be averted.

\section{Regulatory Framework for Drones in Asian Countries \\ 2.1 India}

There are various uses of drones in India for civilian/commercial purposes such as infrastructure (45.2 percent), agriculture (32.4 percent), transport (13 percent), security (10.5 percent), media and entertainment ( 8.8 percent), insurance (6.8 percent), telecommunication (6.3 percent), and mining ( 4.3 percent $).{ }^{20}$ However, the use of drones 
lacked an adequate legal framework. ${ }^{21}$ In a significant development, on August 272018 , the Indian civil aviation regulator, Directorate General of Civil Aviation (DGCA), has come up with the regulation to regulate the operation of civilian drones. The Regulation came into effect on December 1, 2018. ${ }^{22}$ The Regulation issued under the provisions of Rule 15A and Rule 133A of the Aircraft Rules 1937. Before adopting this Regulation, there was a minimal scope of regulations on the use of commercial drones. The "2018 Regulation" legalized the use of drones for civilian purposes and avoided multiple permissions and illegal use. The government also introduced the Digital sky platform for the national unmanned traffic management (UTM) platform that implements "No permission, no take-off (NPNT) policy through these regulations." 23

On March 12 2021, the Indian Ministry of Civil Aviation notified "Unmanned Aircraft System Rules, 2021". This new notification superseded the "2018 Regulation". The notification applies to all UAS registered in India, even if they operate outside Indian territory. It also applies to "all persons seeking to own or possess, or seeking to engage in importing, exporting, manufacturing, trading, leasing, operating, transferring or maintaining a UAS in India." 24

Though the Indian market for drone use is at a nascent stage, there are various uses of the drones already in place for various purposes. ${ }^{25}$ The Rules 2021 provides elaborate provisions on drones categorized into Nano, Micro, Small, Medium, and Large. The Rules classified the norm for considering the Nano Drones into Micro Drones, "if the Nano Drone exceeds the stipulated performance parameters based on (i) the maximum speed (i.e., $15 \mathrm{~m} / \mathrm{s}$ ); or (ii) height (i.e., 15 meters) and range attainable (i.e., 100 meters) from the remote pilot (i.e., performance-based classification)." 26 The previous "2018 Regulation" Nano Drones were exempted from regulatory mechanisms, but the new "2021 Rules" were brought under the regulatory framework with certain exceptions. It is mandatory to obtain a Unique Identification Number (UIN) for all such categories. All imported drones have to get an Equipment Type Approval (ETA) from the Department of Telecommunication and import clearance from DGCA. Only Indian citizens who attained the age of 18 years or any company or body corporate registered and having principal place of business in India can apply for registration of drones and UIN. Unlike 2018 Regulation, the 2021 Rules makes it mandatory for all persons involved in the drone ecosystem to obtain license and registration in the "capacity of an authorized UAS Importer, authorized UAS Manufacturer, authorized UAS Trader, authorized UAS Owner or authorized UAS Operator (together as “Authorised Person"), by making an application to the DGCA through Form UA-1 and in accordance with the conditions prescribed under Rule 6 of the UAS Rules." ${ }^{27}$ It is mandatory to obtain an Unmanned Aircraft Operator Permit (UAOP). The operator is responsible for the safe custody, security, and access control of the RPAS. Any sale of such registered drones shall not be sold or disposed-off to any person without permission from DGCA. Every operator has to obtain a ground training certificate from any flying training organization. The drone must have the following technical requirements as well:

- GNSS for horizontal and vertical position fixing

- Autonomous flight termination system or return home option

- Flashing anti-collision strobe lights

- $\quad$ RFID and GSM SIM Card/NPNT compliant for APP based real-time tracking

- Fire-resistant identification plate inscribed with UIN

- Flight controller with flight data logging capability

Additional facilities required for all RPAs other than Nano and Micro are:

- $\quad$ SSR transponder or ADS - B OUT equipment

- Barometric equipment with capacity for remote sub-scale setting

- Geo-fencing capability

- $\quad$ Detect and Avoid capability

Indian Air Force empowered to monitor movements of RPAs in coordination with the Airports Authority of India. The RPA operators must inform the concerned local police station in writing before commencing the operations. RPA Operators shall carry out a safety risk assessment, hazard identification, and determination of severity and likelihood of hazard on the operation, the sites of emergency operations, including that of launch/recovery sites, must be under the complete control of the operator. No RPA is allowed to operate within a distance of $5 \mathrm{~km}$ from the perimeter of airports at Mumbai, Delhi, Chennai, Kolkata, Bengaluru, and Hyderabad. Other airports within the boundary of $3 \mathrm{~km}$.

There are also restrictions on operations in zones like the Red zone (no-fly areas), yellow zones (require prior approval before flying), and green zones (un-restricted areas). Drone flying up to $400 \mathrm{ft}$. and beyond visual line of sight are allowed. UIN or UAOP issued by the DGCA may be suspended or canceled in any violation of the provisions of this regulation. Aircraft Act, 1934, imposes penalties of imprisonment for a term that may extend up to two years, or fine, extending to Rs.10 Lakhs or with both.

Foreigners are not allowed to use drones in India for any purpose, and they cannot get a license for the use of drones. On March 18 2019, a Chinese tourist was arrested for flying drones over the historic Victoria 
Memorial near Fort William, an important military installation. ${ }^{28}$ In the wake of rising security concerns and as per one estimation, there are 50,000 to 60,000 illegal drones in India ${ }^{29}$; the Ministry of Civil Aviation has directed all the drone owners to voluntarily register their drones on the Digital Sky portal before January 31 $2020 .^{30}$ After enlisting the drone, each will get an Ownership Acknowledgement Number (OAN), and after uploading the information, the owner will receive a Drone Acknowledgement Number (DAN). ${ }^{31}$ Failing to comply with the procedure will make drone operation an offense - endangering someone's life or negligence concerning the use of machinery under the Indian Penal Code, which is punishable up to six months imprisonment. ${ }^{32}$ It also carries a punishment up to two years and fine up to 10 lakhs under the Aircraft Act $1934 . .^{33}$

\subsection{China}

China is the world's largest drone manufacturer, and its market will increase up to worth US\$9 billion in $2020^{34}$; and with an expectation of US\$27 billion by 2025 , the global market projection is US\$43 billion. ${ }^{35}$ Civil Aviation Administration of China (CAAC) $)^{36}$ - the governing body of civil aviation and drones, under the People's Republic of China (PRC) Civil Aviation Law, has adopted the new rules for the regulation of unmanned aircraft (Nishith Desai Associates, 2019, p. 11). There are three-layer regulatory mechanisms provided for drones. ${ }^{37}$ (a) Registration Management - The Aircraft Airworthiness Certification Department of CAAC in May 2017 issued Provisions on the Administration of the Real-name Registration of Civil Unmanned Aircraft, which mandated that the civilian drones weighing 250 grams and above need to register under real names from June 1, 2017. (b) Operation Management - the CAAC in November 2015 issued the Provisions for the Operation of Light and Small Unmanned Aircraft (for Trial Implementation). The Provisions directed that the drones weighing over $7 \mathrm{~kg}$ and beyond visual line of sight (BVLOS) of less than $7 \mathrm{~kg}$ must twin with the drone cloud in real-time. Such twined technology will sound alarms when drones fly into an electric fence safety features useful for protected areas where flying of drones are restricted or limited. The Provisions came into effect on December 29 2015. ${ }^{38}$ There are seven categories of UAS defined under the Provisions. The CAAC released the Fence of Unmanned Aircraft System and Interface Specifications of Unmanned Aircraft and Cloud System to ensure the orderly management of the drone system in October 2017. Just two months after October release, the Ministry of Industry and Information Technology (MIIT) in 2017, issued a Guidance of Promoting and Normalizing Commercial Unmanned Aerial Vehicles' Development to focus on the development of drone digital identification rules and technical solutions (each drone to have a dedicated ID). (c) Standard System - the Office of Standardization Administration of the People's Republic of China released a Guideline on Building a Standard System for Unmanned Aircraft in August 2017. The Guideline sets the objectives and stages of development required to establish a standard for the drone industry. The Guideline divided the phase into two time periods: 2017-18 - aimed to meet market requirements; 2019-20 - intended to promote the establishment of the drone system. Apart from these three stages of regulation, China also keeps checking on drone flight safety requirements. All drones are subject to China's No-Fly Zones (NFZ), and Beijing has been declared entirely as NFZ. The CAAC approves all qualified UAS cloud prodders. All UAS operators have to buy insurance to cover the liability towards third parties on the ground. The UAS operation provisions require a pilot-in-command to be appointed who is directly in charge of the operation of the UAS. The pilot in command shall report all accidents that resulted in substantial injuries or the death of ground personnel, or severe loss of ground property. The pilot should meet the requirements regarding the licenses, certificates, ratings, training, examinations, inspections, and aviation experience in an advisory circular. The operating UAS should have a data record system for recording, replaying, and analyzing each flight data along with an effective air-ground $\mathrm{C} 2$ link. There is a temporary export ban on certain dual-use UAS. The regulations also implemented an effective management system for civilian UAS. There are special provisions for Agricultural UA operating requirements for spraying pesticides, fertilizing, soil treatment, crop reproduction, and insect control.

Apart from these mandates, there are specific general laws for drones: ${ }^{39}$ (a) flying of drones prohibited over people or large crowds. (b) As per the 2019 regulations, $120 \mathrm{~m}$ (400ft) is the maximum altitude permitted for drones flying. (c) Drones under $7 \mathrm{~kg}$ are allowed to fly. (d) Drones weighing $7 \mathrm{~kg}$ to $116 \mathrm{~kg}$ require a license from the CAAC. (e) Drones weighing over $116 \mathrm{~kg}$ need a pilot license and UAV certificate for operation. (f) Flying drones in controlled areas requires prior approval. (g) CAAC approval is mandatory for all commercial drones. (h) Avoid flying near airports and flight paths, and be cautious while flying over built-up areas or people.

\subsection{Hong Kong}

The Air Navigation (Hong Kong) Order 1995 is the primary legislation that lays down the basis of drone regulations. ${ }^{40}$ Since Hong Kong is a densely populated city with busy air traffic, Art 48 of the Order 1995 mandates that "[A] person shall not recklessly or negligently cause or permit an aircraft to endanger any person or property" - here aircraft include drones and offenders are liable to pay fine and imprisonment up to two years. ${ }^{41}$ Article 3, 7, and 100 of Order 1995 require that aircraft weighing above $7 \mathrm{~kg}$ (without fuel) can fly only 
with the Certificate of Registration and Certificate of Airworthiness issued by the Civil Aviation Department (CAD) ${ }^{42}$ Article 100 of the Order classifies drones below $7 \mathrm{~kg}$ of weight as small aircraft used for recreational purposes. Regulation 22 of the Air Transport (Licensing of Air Services) Regulations 1949 mandates that a person has to apply with the CAD before operating drones of any weight for hire or reward. ${ }^{43}$ The commercial operations of drones weighing $7 \mathrm{~kg}$ or more need an application to submit before CAD; however, if the drone weighs less than $7 \mathrm{~kg}$ for recreational purposes, such an application is not required. ${ }^{44}$ The operator has to also abide by the laws relevant in drone flying, such as Telecommunications Ordinance ${ }^{45}$ and Personal Data (Privacy) Ordinance. ${ }^{46}$

There are specific applicable laws for drones as well. In commercial flying, the pilot has to maintain the record of each flight. For commercial operations, the operator has to maintain and submit an operations manual disclosing the procedures while operating - this requirement is critical for CAD to analyze the safety concerns. ${ }^{47}$ Flying of drones within the $5 \mathrm{~km}$ of airports and within 50 meters of a person (other than involved in the operation), vessel, vehicle, or structure except during take-off and landing prohibited. ${ }^{48}$ Other general norms for drone operations are: pilots must maintain visual contact all the time, permission to fly over others' property, should not fly above 90 meters, and do not fly in the night. ${ }^{49}$

\subsection{Singapore}

Singapore is one of the "enthusiastic users" of drones. Its Ministry of Transport heads a multiagency Unmanned Aircraft Systems (UAS) Committee to promote the various uses of drones by public sector agencies for commercial purposes. ${ }^{50}$ The government is also exploring the aspects of drone use in case of emergencies and crises. ${ }^{51}$ Singapore is one of the leading Asian countries which has quickly responded legislatively to encourage drone use. At the same time, Singapore also addresses the concerns arising from drone use. ${ }^{52}$ The umbrella legislation that operates full air navigation is the Air Navigation Act $1966^{53}$, and under the Act, drones are regulated by the Air Navigation Order $1985 .{ }^{54}$ The Act sets out specific prohibitions: ${ }^{55}$ (a) taking photographs in protected areas by drones - fine up to SGD 20,000 or imprisonment up to 12 months or both; (b). Operating over protected areas - fine up to SGD 20,000 or imprisonment up to 12 months or both; (c) Discharge of any substance by drones - fine up to SGD 20,000; and (d) Flying with prohibited items (weapons, biological agents, radioactive substances and other hazardous material) - fine up to SGD 100,000 or imprisonment up to 5 years or both. There are certain activities that require permission as provided in Order: ${ }^{56}$ (a) Operator permit - granted to an applicant to ensure safe operation; (b) Class 1 Activity Permit - required for activities other than recreational or research use of drones, or if it is over 7kg; (c) Class 2 Activity Permit - Required for recreational or research activities. No permit is needed if: (a) if the drone weighs $7 \mathrm{~kg}$ or less; (b) If it is flying $200 \mathrm{ft}$ above sea level or below; (c) If it is flying outside restricted, danger, protected and prohibited areas and $5 \mathrm{~km}$ away from the airports.

The President approved the recent legislation titled "Unmanned Aircraft (Public Safety and Security) Act on May $282015 .{ }^{57}$ The Act adopted a "balanced and sustainable regulatory framework" to encourage drone technology with responsible use. ${ }^{58}$ The Act has brought up significant amendments to the 1966 Act and Order 1985 to develop uniformity.

The objective of the Act was to provide a clear rule for flying the drones and their safe and responsible operations. ${ }^{59}$ The Act also considered the varied uses of drones, and due to this, many operational issues are arising, including reported incidents. Therefore, the Act provides guidelines for "traffic control, surveying, pesticide application to crops, and fire fighting as examples of possible use." 60 Thus, the Act is one of the best and comprehensive legislation with a futuristic scope. However, the Act did not detail the concerns of privacy. ${ }^{61}$ Currently, the privacy concern is governed by the Personal Data Protection Act 2012.62

From April 2 2020, operating unregistered drones with a weight of 250 grams and above has become an offense in recent development. ${ }^{63}$ The two-step registration process is available for the category mentioned above, which involves purchasing a registration label (costing SGD 15) and Completing online registration via the UA portal. The user of drones must be of 16 years of age at the time of registration, or they can register through someone else who is eligible (e.g., the parent or legal guardian) and have obtained permission for the same. The user is accountable for all activities involving registered drones in their name.

\subsection{Japan}

Japan has enacted drone regulation with a focus on commercial activities. However, a regulatory mechanism developed due to concern of terrorism and related security concerns (when a drone was found on the roof of the prime minister's office in 2015). ${ }^{64}$ An amendment was brought to the Aeronautical Act on September 112015 to regulate drone operations. The Amendment came into effect on December 10 2015. The Amendment mandated to obtain permission from the Minister of Land, Infrastructure, Transport, and Tourism while flying the drone in prohibited airspace, viz., the airspace around airports, airspace at or above 150 meters from ground level, above densely inhabited districts. ${ }^{65}$ There are also general rules for drone operations: ${ }^{66}$ (1) Do not operate under the 
influence of alcohol and drugs. (2) Operate only after pre-flight actions. (3) Operate in such a way to avoid collision hazards with airplanes and other drones. (4) Do not operate carelessly or recklessly. (5) Operate in the daytime. (6) Fly within Visual Line of Sight. (7) Keep drones at a 30-meter distance from persons and properties on the ground and water surface. (8) Do not operate over gatherings. (9) Do not transport hazardous or explosive materials by drones. (10) Do not drop any objects from drones. Rules 1 to 4 were added on September 182019 , and if the operator wanted to fly drones regardless of rules 5 to 10 , he has to obtain approval from the Regional Civil Aviation Bureau in advance. The Amendment also provided for a fine up to 500,000 Yen if the above rules were violated. However, if the operator violates Rule 1, he will be liable for imprisonment for up to one year or a fine of up to 300,000 Yen. ${ }^{67}$

Other countries such as Israel ${ }^{68}$, Malaysia ${ }^{69}$, Sri Lanka, and the United Arab Emirates ${ }^{70}$ have also adopted detailed rules for the civilian use of drones. However, it is evident from the analysis of the drone regulations of the countries mentioned above that drone regulations significantly lack uniformity and coherence.

\section{Regulatory Landscape for Drones in Europe and the United States 3.1 European Union}

The market for commercial drones is a highly growing sector with the potential to generate new jobs and economic growth in the European Union (EU). ${ }^{71}$ It will create more than 100,000 jobs, and the economic impact will be more than 10 billion euro over the next 20 years. ${ }^{72}$ Therefore, in this connection, the EU has adopted a regulation for drones to integrate the airspace's flying zone. There have been lengthy deliberations among stakeholders to bring a regulatory uniformity at the EU level. ${ }^{73}$ Most of the EU member countrieshave a welldeveloped laws and regulations for drones. ${ }^{74}$ However, such mechanisms lack uniformity among member States $^{75}$, which prompted the EU to develop a regulation for the entire EU (EU Committee $7^{\text {th }}$ Report, generally see for deliberations). In a significant imitative, the EU adopted Regulation No 216/2008 entitled "Basic Regulation," 76 which establishes the European Aviation Safety Agency (EASA) - a primary body to deal with aviation and drone operations. ${ }^{77}$ (See generally, Lavallee, 2019). The Regulation categorizes drones based on their masses - all drones of $150 \mathrm{~kg}$ or more, except unmanned civil aircraft below $150 \mathrm{~kg}$, and governmental (military or non-military) unmanned aircraft under the regulatory competence of member countries.

Subsequently, the European RPAS Steering Group, EU Commission, and Riga Declaration for "integration of civil remotely-piloted aircraft systems into the European aviation system" discussed drone regulation. ${ }^{78}$ The EASA titled "Introduction of a regulatory framework for the operation of drones" on behalf of the EU in 2015 was the first domain-specific document. ${ }^{79}$ The EASA was tasked to develop a regulatory framework for drone operations and contended that the framework would cover rules for all drones in all weight classes. ${ }^{80}$

Since then, the EASA member countries have concerted a concerted effort to "integrate UAVs into continental airspace." "81 At Amsterdam Drone Week in November 2018, EASA holds a High-Level Conference on Drones to discuss the framework regulation for drones $(\mathrm{McNabb}, 2018)$. It is to be noted that the EU emphasizes safety ahead of the recognized goal: the development of the European drone market. ${ }^{82}$ Amsterdam Declaration sets the roadmap for drone regulation in the EU. ${ }^{83}$ The collective and continued deliberations of the European Union and the EU Parliament for a common regulatory framework to support the drone technology and economy while respecting the safety, privacy, and environmental standards, did result in a common regulation for drones for the EU. ${ }^{84}$ The EU has developed the regulation considering the two essential elements: (a) realizing the urgent need to develop the drone regulation and drones' use in Europe for varied purposes; (b) To overcome the regulatory and technical barriers for drone use and its integration into airspace. ${ }^{85}$

Thus, the EASA has adopted a new regulation common for the entire EU to ensure the smooth development of drone technology and its varied use. The regulation has intended to maintain the highest safety standards as developed for manned aviation. The risk assessment of the operation, fine-tuning of obligations of drone manufacturers and operators for safety, privacy, environment, and security has been the basis of rules formulation of the Regulation. ${ }^{86}$

This Regulation ${ }^{87} 2019 / 947$ will come into force from June $2020^{88}$ and replace member States' rules, thereby placing a common EU regulation on drones. ${ }^{89}$ In this way, the Regulation will create a "truly harmonized drone market in Europe with the highest level of safety." The regulation has adopted the two basic principles: (a) risk-based and proportionate, (b) sharing responsibilities between the EU and the Member States.

The Regulation has provided a detailed framework common for all the Member States. Article 3 of the Regulation has divided three categories of drone operations: (a) Open Category - operations should meet the criteria defined under Article 20, maximum take-off mass should be less than $25 \mathrm{~kg}$ weight, pilot of the drone has to ensure that it is at a safe distance from people and crowd, the pilot has to maintain the visual contact with the drone, must fly within the 120 meters of altitude, should not carry dangerous goods and dump any material. Again it has been divided into three sub-categories. ${ }^{90}$ The open category operations do not need any prior operational authorization or any operational declaration from the operator before the operation. (b) Specific Category - operation requires an operational approval from the competent authority subject to consideration of 
Art 12 or Art 16, or, as defined under Art 5(5), and a declaration has to be made by the operator. The applicant has to perform a risk assessment as provided in Art 11, which has to submit along with the application. ${ }^{91}$ (c) Certified Category - In this category, a certificate of drones and operator has to obtain in under Delegated Regulation (EU) 2019/945, and license of the remote pilot, if applicable. Certified category can be classified only if: certified as per Art 40(1) (a), (b), and (c) of the Delegated Regulation (EU) 2019/945, operation conducted over "assemblies of people," transport of people, or "carriage of dangerous goods, that may result in high risk for third parties in case of accident" and where the competent authority considers that the risk assessment does not adequately mitigate the risk of the operations. ${ }^{92}$

The adoption of the term U-space for supporting the low altitude drones $(120 \mathrm{~m})$ to provide fully automated infrastructure to pilots for safe operation, including air traffic management and details of restricted zones, is a unique feature to harmonize the drone flying space within the airspace. ${ }^{93}$

\subsection{United States}

Deregulation of the U.S commercial air carrier industry in 1978 has seen continued growth. ${ }^{94}$ (FAA Aerospace Forecast 2016-36). The emergence of the drone industry - currently, the US dominates drone manufacturing, and usage has boosted the air carrier industry. ${ }^{95}$ As per FAA Aerospace Forecast 2016-36, drone sales will reach 7 million by $2020 .{ }^{96}$ The possibilities of varied uses for commercial and hobbyist purposes are enormous in the US. ${ }^{97}$ The commercial use of drones by online and logistic companies has generated the public discourse to harmonize the commercial drones into the existing airspace to capture the market shares. ${ }^{98}$

The regulatory framework for drones, despite having such economic and technological viability, the federal and states drone policies are not in sync, which is resulting in tensions among policy-makers at different levels. ${ }^{99}$ The Federal Aviation Administration - a designated body by the US Department of Transportation to govern air navigation, since 2007 adopted a general ban on the use of commercial drones without special permission. ${ }^{100}$ However, a comprehensive legal framework came into existence by the Federal Aviation Modernisation and Reform Act 2012 (FAMRA), directing the FAA to regulate commercial drones in the United States. ${ }^{101}$ Apart from the Federal Act, various State and local governments have also adopted verities of laws to address drones. ${ }^{102}$ As of March 2017, 133 local governments in 31 States of the US housing over 30 million people have developed rules for drones. ${ }^{103}$

FAA in the 1990s allowed occasional drone operations in "normal airspace" for non-military governmental use. ${ }^{104}$ (Boucher, 2014, p. 16). During those periods, private institutions could also operate drones with permission for non-commercial purposes relating to research and training. Public authorities were required to obtain Certificates of Waiver or Authorisation (COAs) before use. Flying of drones in "Class B" air space (near populated areas) was not permitted. Such authorization, however, was not required for drone operations below 400 feet $(122 \mathrm{~m})$.

The FAMRA brought a significant policy shift by allowing the operation of the commercial drone is subject to provisions of the Act. ${ }^{105}$ The Act focuses on developing a full-scale unmanned aircraft system (UAS) for drone operations and integrating such a system into the national airspace system (NAS). Congress directed the FAA to integrate the UAS into NAS by September 2015. However, the FAA could not do so and missed several mandates. ${ }^{106}$ (Chen, 2017, p. 519). The Act prohibits the FAA Act from regulating the drones ("model aircraft") used exclusively for "hobby" or "recreational" purposes. ${ }^{107}$ The Code of Federal Regulation, Part 101 governs the Model aircraft flown exclusively for recreational purposes.

The Regulation states that the model aircraft operator must abide while operating the "community-based set of safety guidelines." The Model aircraft should be programmed as per the "nationwide community-based organization [al]" guidelines, should not weigh more than 55 pounds unless certified by a community-based organization, do not interfere with any manned aircraft while operating and when flying within 5 miles of an airport. The operator has to inform the airport operator and airport air traffic control tower before flying within the restricted zone. Such operation of model aircraft should not endanger the safety of the national airspace system. ${ }^{108}$ Such hobbyists cannot be hired for services unless he has obtained the Remote Pilot Certificate under Part 107. ${ }^{109}$ The FAMRA has also focused on developing the "small unmanned aircraft system" to boost hobbyist and recreational use. For this, the FAA launched an online registration system on December 21, 2015. The mandate was to register all drones weighing more than 0.55 pounds ( 250 grams) and less than 55 pounds. ${ }^{110}$ With a temporary halt due to the order from US Appeals Court in May 2017, the registration process was reinstated from December $2017^{111}$ with the effect of the National Defense Authorization Act (NDAA) $2018 .{ }^{112}$ The NDAA 2018 replaces the Special Rule for Model Aircraft provided under FAMRA and prescribed certain new conditions for recreational use. ${ }^{113}$ However, the Act is not yet fully implemented as the FAA is evaluating the impacts of changes. ${ }^{114}$

Intending to integrate the UAS into NAS, as aspired by the FAMRA - accommodation, integration, and evolution ${ }^{115}$, in 2016, the FAA adopted Part 107 (Small Unmanned Aircraft Systems/sUAS). ${ }^{116}$ Part 107 applies to "registration, airman certificate, and operation" of sUAS within the US except the drones regulated under Part 
101. Part 107 regulates various aspects of commercial operations. Such as drones weighing more than 5 pounds need to be registered with the Federal agency, commercial drone operators have to obtain a license and airman certificate, and flying at night, at an altitude higher than 400 feet and outside the pilot's visible sight is prohibited. ${ }^{117}$ From January 13, 2020, the process of obtaining an airman certificate has improved. ${ }^{18}$ The new Knowledge Testing changes apply to all pilots of manned and unmanned aircraft. ${ }^{119}$

Certain vital concerns have been the challenges before the US policy-makers in developing the drone regulations ${ }^{120}$, and various cases have come before the courts as well. ${ }^{121}$ Privacy issues while flying over private property - which has roots in Constitutional and Common Law ${ }^{122}$, safety and security, insurance ${ }^{123}$, and liability towards third parties ${ }^{124}$ are a legal concern in the US.

\section{Role of the International Civil Aviation Organisation (ICAO) in Drone Regulation}

To develop internationally workable standards, international organizations as "norm entrepreneurs" have successfully contributed toward the enrichment of the making of international law. The "normative and ideational concerns" are the chauffeur of international organizations' international politics and life in developing the global norms. ${ }^{125}$

Since there is no mandatory international mechanism available to systematize drone regulation globally, the national regulations also lack uniformity and a systematic approach. The International Civil Aviation Organisation (ICAO), being a specialized international body to regulate civil aviation, has developed various "norms" such as Standards and Recommended Practices (SARPs) and on the request of the member States currently working on the Emission Trading Schemes (ETS) to curb the aviation emissions. The ICAO, therefore, has significantly influenced not only international civil aviation but also national civil aviation regulatory frameworks. Therefore, it is a wise initiative by the international community to bestow ICAO with the responsibility to develop and maintain the Unmanned Aircraft System (UAS). Since drone significantly encroaches on the operational zone of aircraft, which it has been using traditionally. The prior experience of ICAO could be pivotal to develop a consensual international framework for drone regulations.

The ICAO has placed the drone under the list of "global priorities," and States have also requested the ICAO for deliberating the issue with the involved stakeholders. ${ }^{126}$ The ICAO held the "first truly" global Remotely Piloted Aircraft Systems (RPAS) Symposium on 23 -25 March 2015 in Montreal, Canada. The symposium was titled "Remotely Piloted or Piloted: Sharing One Aerospace System." 127 The objective of the symposium was to provide a platform for States, international organizations, and other stakeholders "to identify how existing aviation rules need to evolve to meet the challenges involved in welcoming the RPAS community and to examine the alignment between ongoing RPAS development and supporting regulatory provisions." 128 The symposium also showcased the "opportunities created by the integration of RPAS into the global aerospace system." 129

The Second Global Remotely Piloted Aircraft Systems Symposium (RPAS2017) from 19 to September 21 2017, held in Montreal, Canada, "to provide an international platform for licensing authorities, training facilities, regulators and the industry to exchange ideas and share best practices for the further development of an RPAS regulatory framework." 130 The symposium agenda included the developments of the new Remote Pilot License (RPL), implementation of approved training programs, RPAS operations, and its impacts on human performance. ${ }^{131}$ It also provided an opportunity for networking, collaboration, and coordination among various stakeholders such as States and industries.

The ICAO organized another symposium to understand and consider the drone industries' concerns, titled “Drone Enable, ICAO’s Unmanned Aircraft Systems (UAS) Industry Symposium” on 22-23 September 2017 at Montreal, Canada. The symposium was to provide "a unique opportunity for States, international organizations, industry, academia and other stakeholders to share their research, best practices and lessons learned related to unmanned aircraft system traffic management system (UTM)."132

The ICAO organized the Third RPAS Symposium from 10 to September 12 2018, in Chengdu, China. The theme of the symposium was "from accommodation to integration." It was to "bring together key stakeholders from industry, academia, government and international organizations in the aviation sector to exchange research, best practices, lessons learned and respective challenges." ${ }^{133}$ The main focus was to deliberate on the complex issues, such as categorization for RPAS operations, which need to address collectively to integrate RPAS into the global aviation system. It focused on finding solutions after due deliberations with the stakeholders to assist the global "UAS activities and safely integrate UAS traffic management systems and existing conventional air traffic management systems." 134 The symposium was themed "transitioning from segregation to integration." The symposium organized with the "Unmanned Aviation Week" hosted a series of events. The event concluded on the note that the "responsive regulatory framework [is needed] to support the safe integration of unmanned air traffic innovations into the global aviation network." ${ }^{355}$ Speaking at the event, the ICAO's Secretary General Dr.Fang Liu stressed the need for safe and harmonized airspace management priorities for unmanned aircraft and drones. 
Besides working on developing standards for international operations, the ICAO Besides working on developing standards for international operations, the ICAO also requested the Member States in 2016 during $39^{\text {th }}$ Assembly to create "a practical regulatory framework for national UAS activities." 136 The ICAO is also mooting for the "creation of a single global drone registry, as part of broader efforts to come up with common rules for flying and tracking unmanned aircraft." 137 It is also developing the UAS traffic management (UTM) concept to bring harmony between manned navigation and unmanned flying.

The ICAO Expert Group on Remotely Piloted Aircraft Systems Panel (RPASP) has devised a mechanism called "Concept of Operations for International IFR (instrument flight rules) Operations" in 2017. The CONOPS intends to outline the operational details of manned and unmanned aircraft to ensure a common understanding and how drones could be "ultimately integrated into the airspace. It also details the conventional view of ICAO and States to prioritize and address the concerns associated with the integration of drones into the airspace. The CONOPS will also assist the Air Navigation Commission, States, and ICAO expert groups in developing the SARPs, and Procedures for Air Navigation Services (PANS). ${ }^{138}$

The ICAO, after enormous discussions and deliberations, has developed a Model UAS Regulations. ${ }^{139}$ These Model regulations are open for comment from the States till February 28 2020. The Model is not "prescriptive, mandatory" or pre-empt for States' legal structure. The Model took due consideration that all States "might" be having different needs, and therefore, they are free to adapt the Model, as appropriate, to address the specific need. ${ }^{140}$

\section{Conclusion}

The drone regulations varied in country to country, and there is no uniformity of rules and procedures across frontiers. Different approaches in drone regulations are visible among the countries. The EU and the US have focused more on integrating UAS into ANS, and concern of privacy has been the foremost priority. Whereas the Asian countries (among discussed in the paper) except Singapore, China, India, and Hong Kong do not have specific legislation and concerns of privacy and environment largely depend on other laws. For example, India does not have a provision for the confidentiality of data and permission to take the prior consent of people before drone photography. In the US, there is a multiplicity of regulations: federal, state, and local levels, which lack uniformity.

On the other hand, the newly adopted common drone regulation for the entire EU is yet to force. It is also well understood that the new drone technologies are capable of cross-border navigation for commercial purposes. The recent use of military drones for an attack on Saudi Arabian refineries and the killing of Iran General Qassem Soleimani in Iraq could tighten the regulatory framework even for civilian drones duesecurity concernsrity. ${ }^{141}$

Due to the high risk involved in drone operations, the availability of insurance in case of accidents is not available in the present days. Physical losses to the drones, properties and third persons are areas of concern that require regulatory and policy decisions. The operation of drones requires trained pilots, and only some of the countries like India require specialized training for drone operators. There is no uniform standard, and the licensing procedure for drone operators is also a serious policy concern.

In this regard, for effective drone regulation, the role of ICAO is indispensable for balancing technological development and concerns arising from its use. As mooted by the ICAO, developing an international registry system for drones could become a recommendation. The ICAO can also play a very active role in developing international regulations for drones. The ICAO drafted Model regulations (still open for States' comment till February 28 2020) can bring uniformity among States in domestic regulations for drones.

\section{Notes}

Kardasz P. et al. (2016) 'Drones and Possibilities of Their Using', Journal of Civil \& Environmental Engineering, Vol.6, No. 3, p. 1.

2 Custers B. (2016). Drones Here, There and Everywhere Introduction and Overview in Bart Custers, ed., The Future of Drone Use: Opportunities and Threats from Ethical and Legal Perspectives. The Hague, ASSER Press, p. 5.

3 Crilly, R (2011). Drones First Used in 1848, The Telegraph, [online] https://www.telegraph.co.uk/news/worldnews/northamerica/8586782/Drones-first-used-in-1848.html (accessed 28 January 2020).

4 Jones T. (2017). International Commercial Drone Regulation and Drone Delivery Service. RAND Corporation, Calif [online] https://www.rand.org/pubs/research reports/RR1718z3.html (accessed 28 January 2020).

5 Boucher P. (2014). Civil Drones in Society. JRC Science and Policy Reports, p. 4. 
6 Wallace, Gregory. (2013). Amazon Says Drones Deliveries are the Future, CNN Business. [online] https://money.cnn.com/2013/12/01/technology/amazon-drone-delivery/index.html (accessed 30 January 2020).

7 Lohn, Andrew J., Timothy R. Gulden, Jia Xu, Therese Jones, Kenneth Kuhn, and William Welser IV, What's the Buzz? The Drones Are Here. Santa Monica, CA: RAND Corporation, 2018 [online] https://www.rand.org/pubs/research_briefs/RB9995.html. (accessed 22 May 2020).

8 Jones T., supra note 4.

9 Economic Times, March 26, 2018 [online] https://economictimes.indiatimes.com/news/defence/indiafastest-growing-market-for-unmanned-aerial-vehicles/articleshow/63466658.cms (accessed 28 January 2020).

10 Hazim Shakhatreh et al., "Unmanned Aerial Vehicles: A Survey on Civil Applications and Key Research Challenges, (2018), [online] https://arxiv.org/pdf/1805.00881.pdf (accessed 20 November 2019).

11 Cracknell A. (2017). 'UAVs: Regulations and Law Enforcement', 38 International Journal of Remote Sensing, Vol. 38, p. 3054.

12 Clarke R. (2014). 'Understanding the Drone Epidemic', Computer Law \& Security Review Vol. 30 No. 3, p. 230.

13 Nishith Desai Associates. (April 2018). Unraveling the Future Game of Drones: Can they be legitimized? [online] http://www.nishithdesai.com/fileadmin/user_upload/pdfs/Research\%20Papers/Unravelling_The_Future_Ga me of Drones.pdf (accessed 22 May 2020).

14 Convention on International Civil Aviation ("Chicago Convention") 7 December 1944 (1944) 15 U.N.T.S. 295, [online] https://www.refworld.org/docid/3ddca0dd4.html (accessed 22 November 2019).

15 ICAO,[online] https://www.icao.int/about-icao/Pages/default.aspx (accessed 22 November 2019).

16 Ibid.

17 Peter van Blyenburgh, (2018),[online] http://www.unmannedairspace.info/commentary/icao-drones-threatdiffering-national-regulations-gaps-standards/ (accessed 23 November 2019).

18 IATA, https://www.iata.org/whatwedo/safety/Pages/drones.aspx (accessed 23 November 2019).

19 Library of Congress, Regulation of Drones: Comparative Analysis, [online] https://www.loc.gov/law/help/regulation-of-drones/comparative.php (accessed 29 January 2020).

20 PWC, [online] https://www.pwc.pl/pl/pdf/clarity-from-above-pwc.pdf (accessed 28 January 2020).

21 Rajagopalan R. P. and Krishna R. (2018), 'Drones: Guidelines, Regulations, and Policy Gaps in India' ORF Occasional Paper 145, p. 5.

22 DGCA, [online] http://dgca.nic.in/cars/D3X-X1.pdf (accessed 20 November 2019).

23 PIB, [online] http://pib.nic.in/newsite/PrintRelease.aspx?relid=183093(accessed 20 November 2019).

24 Aniruddha M. and Huzefa T. (2021), 'India: Drone Law 2021: New Regime, Old Problems', The National Review Vol. XI, No. 97.

25 Padmanabhan A. (2017). Civilian Drones and India's Regulatory Responses. Carnegie India, p. 6, [online] https:/carnegieindia.org/2017/03/10/civilian-drones-and-india-s-regulatory-response-pub-68218 (accessed 25 November, 2019).

26 Supra note 24.

27 Ibid.

28 India Today, March 18, 2019,[online] https://www.indiatoday.in/crime/story/kolkata-chinese-touristarrested-for-flying-drone-near-army-base-in-fort-william-1480622-2019-03-18 (accessed 25 November 2019).

29 Live mint, [online] https://www.livemint.com/news/india/register-drones-by-january-31-or-face-actionaviation-ministry-11578914525113.html (accessed 16 January 2020).

30 The Hindu Daily, January 13, 2020, New Delhi, [online] https://www.thehindu.com/news/national/indiastarts-voluntary-disclosure-scheme-for-persons-flying-non-compliant-drones/article30556659.ece, (accessed 16 January 2020).

31 DGCA, [online] https://dronenlisting.dgca.gov.in/ (accessed 29 January 2020).

32 Supra note 30.

33 Ibid.

34 Reuters, December 22, 2017 [online] https:/www.reuters.com/article/us-china-drones/chinas-drone-marketto-be-worth-9-billion-by-2020-industry-ministry-idUSKBN1EG0MX (accessed 29 January 2020).

35 CISION PR Newswire, [online] https://www.prnewswire.com/news-releases/china-drone-markets-20122018--2019-2024-300964487.html (accessed 29 January 2020).

36 CAAC, [online] http://www.caac.gov.cn/en/GYMH/ZYZN/ (accessed 25 November 2019).

37 Low-Altitude Connected Drone Flight Safety Test Report, 31 January 2018, [online] 
http://www.caac.gov.cn/en/HYYJ/NDBG/201802/P020180227616856973062.pdf (accessed 25 November 2019).

38 Drone Laws in China, [online] https://uavcoach.com/drone-laws-in-china/ (accessed 26 November 2019).

39 China Drone Laws, [online] https://uavsystemsinternational.com/pages/china-drone-laws/ (accessed 26 November 2019).

40 Air Navigation (Hong Kong) Order 1995, [online] https://www.elegislation.gov.hk/hk/cap448C (accessed 27 November 2019).

41 Civil Aviation $\quad$ Department $\quad$ Kong), [online] https://www.cad.gov.hk/english/Unmanned_Aircraft_Systems.html\#1 (accessed 26 November 2019).

42 Consultation Paper, (Regulation of Unmanned Aircraft Systems in Hong Kong Consultancy Study and Way Forward), [online] https://www.cad.gov.hk/reports/UAS_public_consultation_Eng.pdf (accessed 26 November 2019).

43 Air Transport (Licensing of Air Services) Regulations, (Cap. 448, sections 12 and 13(6)) 1949, [online] https://www.elegislation.gov.hk/hk/cap448A (accessed 26 November 2019).

44 Drone Laws in Hong Kong, [online] https://uavcoach.com/drone-laws-in-hong-kong/ (accessed 26 November 2019).

45 Telecommunications Ordinance 2000 (Cap.106), [online] https://www.elegislation.gov.hk/hk/cap106 (accessed 27 November 2019).

46 Personal Data (Privacy) Ordinance 1996, (Cap. 486), [online] https://www.elegislation.gov.hk/hk/cap486

(accessed 27 November 2019).

47 Supra note 44.

48 Ibid.

49 Ibid.

50 Desker B. and Bitzinger R. A. (2016), 'Proliferated Drones: A Perspective on Singapore' [online] http://drones.cnas.org/wp-content/uploads/2016/06/A-Perspective-on-SingaporeProliferated-Drones.pdf (accessed 27 November 2019).

51 Ibid.

52 Chen S. (2017), "The Regulatory Framework for Aerial Imaging by Recreational Users of "drones" in Singapore: Old and Emerging Issues and Some Possible Solutions', Singapore Academy of Law Journal, Vol. 29, No. 1, p. 129. Research Collection School of Law.

53 Air Navigation Act 1966 (Revised Ed. 2014), (Chapter 6), [online] https://sso.agc.gov.sg/Act/ANA1966 (accessed 28 November 2019).

54 Air Navigation Order 1985 (Revised Ed. 1990), [online] https://sso.agc.gov.sg/SL/ANA1966OR2?DocDate $=20121214$ (accessed 28 November 2019).

55 Rajah \& Tann Asia, 'Are You Breaking the Law by Flying a Drone?', (July 2019), [online] https://eoasis.rajahtann.com/eoasis/lu/pdf/2019_07_Law_Flying_Drone.pdf (accessed 22 May 2020).

56 Ibid.

57 Unmanned Aircraft (Public Safety and Security) Act 2015 (No. 16 of 2015), [online] https://sso.agc.gov.sg/Acts-Supp/16-2015/Published/20150529?DocDate=20150529 (accessed 28 November 2019).

58 Chen S., supra note 52, p. 129.

59 Desker B. and Bitzinger R. A., supra note 50, p. 15.

60 Ibid.

61 Rajah \& Tann Asia, supra note 55, p. 3.

62 Personal Data Protection Act 2012 (No. 26 of 2012), [online] https://sso.agc.gov.sg/Act/PDPA2012 (accessed 29 November 2019).

63 CAAS, [online] https://www.caas.gov.sg/public-passengers/unmanned-aircraft/ua-regulatoryrequirements/ua-registration

(accessed 29 November 2019).

64 Rajagopalan R. P. and Krishna R., supra note 21, p. 23.

65 [online] http://www.mlit.go.jp/en/koku/uas.html (accessed 16 January 2020).

66 Ibid.

67 Ibid.

68 [online] https://www.loc.gov/law/help/regulation-of-drones/israel.php (accessed 16 January 2020).

69 [online] http://aip.dca.gov.my/aip\%20pdf\%20new/AIC/AIC\%20200804.pdf (accessed 16 January 2020).

70 [online] https://www.gcaa.gov.ae/en/Pages/uas_old.aspx\#Menu1(accessed 16 January 2020).

71 EC, [online] https://www.consilium.europa.eu/en/policies/drones/ (accessed 30 November 2019).

72 Karpowicz J. (2017), 'Exploring Commercial Drone Opportunities and Regulation Across Europe in 2017' 
[online] http://www.expouav.com/europe/wpcontent/uploads/sites/11/2017/01/UAV_Europe_Commercial_ Drone_Report_2017.pdf (accessed 27 November 2019).

73 House of Lords EU Committee ( $7^{\text {th }}$ Report of Session 2014-15), [online] https://publications.parliament.uk/pa/ld201415/ldselect/ldeucom/122/122.pdf (accessed 2 December 2019).

74 Cracknell A., supra note 11, p. 3054.

75 Karpowicz J., supra note 72.

76 Regulation (EC) No 216/2008, [online] https://www.easa.europa.eu/sites/default/files/dfu/approvals-andstandardisation-docs-syllabi-Syllabus_216_General_05032009.pdf (accessed 3 December 2019).

77 Layallee C. (2019), 'The EU policy for civil drones: the challenges of governing emerging technologies', Policy Brief Institute of European Studies, 1.

78 Bernauw, K. (2016), 'Drones: The Emerging Era of Unmanned Civil Aviation', Zbornik, p. 237.

79 European Aviation Safety Agency (Technical Opinion), 'Introduction of a Regulatory Framework for the Operation of Unmanned Aircraft', [online] https://www.easa.europa.eu/sites/default/files/dfu/Introduction $\% 20 \mathrm{of} \% 20 \mathrm{a} \% 20$ regulatory $\% 20$ framework $\%$ 20for\%20the\%20operation\%20of\%20unmanned\%20aircraft.pdf (accessed 3 December 2019).

80 Cracknell A., supra note 11, p 3058.

81 Plaza J. (6 March 2019), 'Understanding the Framework for Pan-European Drone Regulations', [online] https://www.expouav.com/news/latest/framework-drone-regulations-europe/（accessed 27 November 2019).

82 EC, (26 June 2018), [online] https://www.consilium.europa.eu/en/press/press-releases/2018/06/26/ensuringaviation-safety-and-safe-use-of-drones-council-signs-off-on-easa-reform/ (accessed 3 December 2019).

83 Drones Amsterdam Declaration, Amsterdam (28 November 2018), [online] https:/www.easa.europa.eu/sites/default/files/dfu/Drones\%20Amsterdam\%20Declaration\%2028\%20Nov\% 202018\%20final.pdf (accessed 5 December 2019).

84 Campos V. S. (2018), 'European Union Policies and Civil Drones' in edited book Ethics and Civil Drones. Eds. M. de Miguel and V. Santamarina Campos. Springer, p. 39.

85 Ben Hayes, Chris Jones, and Eric Topfer, (Eurodrones Inc, 2014), p. 7. [online] http://www.statewatch.org/news/2014/feb/sw-tni-eurodrones-inc-feb-2014.pdf (accessed 5 December 2019). See also, Hayes B. Topfer E. (2014). Report of EURODRONES Inc. [online] https://www.statewatch.org/news/2014/feb/sw-tni-eurodrones-inc-feb-2014.pdf (accessed 27 November 2019).

86 EASA, [online] https://www.easa.europa.eu/drones-regulatory-framework-timeline (accessed 25 December 2019).

87 EU Implementing Regulation 2019/947 of 24 May 2019 'on the rules and procedures for the operation of unmanned [online] aircraft', https://eur-lex.europa.eu/legalcontent/EN/TXT/PDF/?uri=CELEX:32019R0947\&from=EN (accessed 6 December 2019).

88 EASA, [online] https://www.easa.europa.eu/easa-and-you/civil-drones-rpas (accessed 25 December 2019).

89 Drone Rules, [online] https://dronerules.eu/sl/professional/eu_regulations_updates (accessed 25 December 2019).

90 Supra note 86, Art 4.

91 Ibid. Art 5.

92 Ibid Art 6

93 EASA, 'Safe operation of drones in Europe: Update on EASA's Activities', [online] https://www.easa.europa.eu/sites/default/files/dfu/217603_EASA_DRONES_LEAFLET\%20\%28002\%29_f inal.pdf (accessed 7 December 2019).

94 FAA Aerospace Forecast, Fiscal Years 2016-2036, [online] https://www.faa.gov/data_research/aviation/aerospace_forecasts/media/fy201636_faa_aerospace_forecast.pdf

95 Nishith Desai Associates, 'India Opens Skies for Drones - Strategic, Legal and Tax Analysis', (August 2019), p. 5. [online] http://www.nishithdesai.com/fileadmin/user_upload/pdfs/Research_Papers/IndiaOpens-Skies-for-Drones-Legal-Tax-Analysis.pdf

96 Brandi Jewett and Grand Forks Herald, 'Drone Sales Could Reach 7 Million by 2020, FAA Says' (25 March 2016), [online] https:/www.govtech.com/public-safety/Drone-Sales-Could-Reach-7-Million-by2020-FAA-Says.html (accessed 7 December 2019).

97 Turza N. R. (2014). Dr. Dronelove, 'How we should All Learn to Stop Worrying and Love Commercial Drones', North Carolina Journal of Law \& Technology 15. See also Chen G. Y. (2017), 'Reforming the Current Regulatory Framework for Commercial Drones: Retaining American Businesses' Competitive Advantage in the Global Economy', 37 Northwestern Journal of International Law \& Business 37(3), 513. 
$98 \quad$ Ibid.

99 Abby Lemer, et al., 'Drone Policy Overview', Purdue Policy Research Institute, [online] https://docs.lib.purdue.edu/cgi/viewcontent.cgi?article=1010\&context=gpripb (accessed 6 December 2019).

100 Chiate J. (1 November 2013), 'Drone Pilot Challenges FAA on Commercial Flying Ban', [online] https://www.scientificamerican.com/article/drone-pilot-challenges-faa-commercial-flying-ban/ (accessed 27 November 2019).

101 FAA Modernization and Reform Act 2012, Public Law No. 112 -95, (Feb. 14, 2012), [online] https://www.congress.gov/112/plaws/pub195/PLAW-112pub195.pdf (accessed 7 December 2019).

102 Cody N. (2018), 'Flight and Federalism: Federal Preemption of State and Local Drone Laws', Washington Law Review 93, p. 1504.

103 Arthur Holland Michel, 'Drones at Home: Local and State Drone Laws', (March 2017), [online] https://dronecenter.bard.edu/files/2017/03/CSD-Local-and-State-Drone-Laws-1.pdf (accessed 8 December 2019).

104 Boucher P., supra note 5, p. 16.

105 Cody N. supra note 102, p. 1501

106 Chen G. Y. (2017), 'Reforming the Current Regulatory Framework for Commercial Drones: Retaining American Businesses' Competitive Advantage in the Global Economy', 37 Northwestern Journal of International Law \& Business 37(3), 519.

107 Ibid.

108 Ibid. $\$ 101.43$

109 Peter Sachs, 'Hiring a hobbyist? You might be committing a federal crime', (12 July 2017), [online] https://dronelawjournal.com/ (accessed 8 December 2019).

110 Unmanned Aircraft Systems, [online] https://www.faa.gov/data research/aviation/aerospace forecasts/media/unmanned aircraft systems.pdf (accessed 9 December 2019).

111 Ibid.

112 FAA Reauthorisation Act 2018, H. R 302, [online] https://www.congress.gov/115/bills/hr302/BILLS115hr302enr.pdf (accessed 8 December 2019).

113 FAA, [online] https://www.faa.gov/news/updates/?newsId=91844 (accessed 10 December 2019).

114 Ibid.

115 FAA, 'Integration of Civil Unmanned Aircraft Systems (UAS) in the National Airspace System (NAS) Roadmap', (First Edition 2013), [online] https://www.faa.gov/about/plans_reports/modernization/media/Sec.332(a).pdf (accessed 8 December 2019).

11614 CFR Part $107^{-}$Small Unmanned Aircraft Systems, [online] https://avsport.org/UAS/ground/PART\%20107.pdf (accessed 9 December 2019).

117 Cody, supra note 102, p. 1495. See also [online] https://www.faa.gov/uas/media/Part_107_Summary.pdf (accessed 27 November 2019).

118 FAA, [online] https://www.faa.gov/uas/ (accessed 29 January 2020).

119 Ibid.

120 Dolan A. M. and Thompson II R. M. (2013), 'Integration of Drones into Domestic Airspace: Selected Legal Issues, Congressional Research Services. [online] https://fas.org/sgp/crs/natsec/R42940.pdf (accessed 27 November 2019).

121 Turza, supra note 97.

122 Chen G. Y., supra note 106.

123 North D. (2015), 'Private Drones: Regulations and Insurance', Loyola Consumer Law Review 27, 2.

124 Carr E. B. (2013), 'Unmanned Aerial Vehicles: Examining the Safety, Security, Privacy, and Regulatory Issues of Integration into U.S. Airspace', National Centre for Policy Analysis.

125 Finnemore M. and Sikkink K. (1998), 'International Norm Dynamics and Political Change', International Organization. Vol.52, No.4, p. 887.

126 ICAO UAS UTM - $\quad$ Request for Information, [online] https://www.icao.int/Meetings/DRONEENABLE3/Documents/ICAO\%20Request\%20for\%20Information \%20(RFI)\%202019.pdf (accessed 16 December 2019).

127 ICAO RPAS 2015, [online] https://uvs-international.org/docs/ICAO-RPAS-Symposium-2015.pdf (accessed 16 December 2019).

128 ICAO RPAS 2015, [online] https://www.icao.int/Meetings/RPAS/Pages/default.aspx (accessed 16 December 2019).

129 Ibid.

130 ICAO RPAS 2017, [online] https://www.icao.int/Meetings/RPAS17/Pages/default.aspx (accessed 17 
December 2019).

131 Ibid.

132 Ibid.

133 ICAO RPAS 2018, [online] https://www.icao.int/Meetings/RPAS3/Pages/default.aspx (accessed 17 December 2019).

134 ICAO, [online] https://www.icao.int/Newsroom/Pages/ICAO-issues-call-for-innovative-solutions-fordrone-airspace-management.aspx (accessed 20 December 2019).

$135 \mathrm{ICAO}, \quad$ [online] https://www.icao.int/Newsroom/Pages/ICAO-Secretary-General-stresses-safe-andharmonized-airspace-management-priorities-for-unmanned-aircraft-and-drones.aspx $\quad$ (accessed 20 December 2019).

136 Ibid.

137 Allison Lampert, 'U.N. Aviation Agency to call for Global Drone Registry', (9 September 2017), [online] https://www.reuters.com/article/us-aviation-drones/u-n-aviation-agency-to-call-for-global-drone-registryidUSKCN1BJ2CL (accessed 20 December 2019).

138 ICAO RPAS Concept of Operations for International IFR Operations (March 2017), [online] https://www.icao.int/safety/UA/Documents/ICAO\%20RPAS\%20Concept\%20of\%20Operations.pdf (accessed 21 December 2019).

139 ICAO Model Regulations Part 101 and 102, [online] https://www.icao.int/safety/UA/Model\%20UAS\%20Regulations/Model\%20UAS\%20Regulations/Model\% 20UAS\%20Regulations\%20-\%20Parts\%20101\%20and\%20102.pdf (accessed 25 December 2019), and ICAO Model Regulation 149, [online] https://www.icao.int/safety/UA/Model\%20UAS\%20Regulations/Model\%20UAS\%20Regulations/Model\% 20UAS\%20Regulations\%20-\%20Part\%20149.pdf (accessed 25 December 2019).

140 ICAO, [online] https://www.icao.int/safety/UA/UASToolkit/Pages/Narrative-Regulation.aspx, (accessed 10 January 2020).

141 Anil Sasi and Sandeep Singh, 'Qassem Soleimani killing prompts Govt to tighten drone rules', (10 January 2020), [online] https://indianexpress.com/article/india/soleimani-killing-prompts-govt-to-tighten-dronerules-6209028/ (accessed 10 January 2020). 